\title{
Social Economy, Third Sector and Solidarity Relations: A Conceptual Synthesis from History to Present
}

\author{
Frank Moulaert and Oana Ailenei
}

[Paper first received, June 2004; in final form, June 2005]

\begin{abstract}
Summary. This paper attempts to provide a clear perspective on defining the social economy today. It addresses the question of the relevance of a unifying concept with its need to embrace the existing diversity of approaches and concepts. To this end, it surveys both historical and contemporary academic literature, as well as practice-rooted conceptualisations of the social economy. The first section outlines the analytical challenges to a reconstruction of the social economy concept. The second enhances the historical and space-bound diversity in theorising and institutionalising social economy practices. Section 3 focuses on contemporary reconceptualisations of the social economy in Francophone and Anglo-Saxon literature, while section 4 then suggests improvements to current 'social economy' concepts, by linking them to both the lessons of history and the views of social economy practitioners today.
\end{abstract}

\section{Introduction}

This paper reviews the various meanings of the term 'social economy', especially as used in Francophone and Anglo-Saxon academic literature and institutional practice over the past 150 years. ${ }^{1}$ The choice of this long time-span and wide linguistic area is justified by the purpose of the analysis-i.e. to evaluate the relevance of various concepts used in the analysis of social economy dynamics and how they can contribute both to a better understanding of social innovation in the contemporary globalising economy and to the construction of shared concepts to underpin future social economy research, action and policy. Despite a wide proliferation of terminologies, there is increasing osmosis among the terms used; however, their real meaning can only be fully grasped when understood within the institutional contexts and epochs from which they arose.

Social innovation in the economy is mainly about the (re)introduction of social justice into production and allocation systems. Although current literature on the social economy addresses the challenge of bringing social justice values back into the economyfor example, by combating social exclusion, fostering development in particularly deprived localities and reinventing solidarity in production relations-it says little, and that inadequately, on the analytical questions arising from current social economy practice. The existing literature surveys (for example, Salomon and Anheier, 1995; Laville and Delfau, 2000; Leyshon et al., 2003) deal with a variety of features of social economy initiatives such as redistribution of income 
and wealth within the market economy, various allocation systems and their political governance, solidarity and reciprocity relations, satisfaction of alienated individual and collective needs, the role of the public, private and third sector in operating and governing the social economy, and global governance as an alternative for Keynesianism, but do not establish the theoretical links between them. Verifying these links is a key condition of the recognition of the factors and mechanisms of 'reproducibility' of both the social economy today and its governance.

A large part of the literature uses an historical perspective, but fails to address the analytical consequences of the history- and context-bound challenges of each epoch and social space for the construction of a theory of the features of the social economy with, on the one hand, a necessary compromise between generally shared concepts and processes and, on the other, specific terminology referring to particular contexts and institutions. Awareness of this methodological challenge gives definition to this paper. The overall starting-point is that each epoch has its own socioeconomic conditions bringing subsequent opportunities and challenges to the lien solidaire (solidarity bond) which it produced. As section 2 shows, when the economic growth engine starts to stutter, formal distribution mechanisms begin to fail and new social forces develop and give rise to alternative institutions and mechanisms of solidarity and redistribution as a means of addressing the failures of the institutions of the socioeconomic movements to guarantee solidarity among economic agents. The survey claims that, within the historically produced social spaces over the past 150 years, different periods can be distinguished in which these spaces have developed their own institutional initiatives to combat poverty, either within the formal state (social policy) and market system (entrepreneurial initiative, employment), or within 'alternative circuits'. Most of these periods also delivered their own philosophical and theoretical analysis of exclusion and solidarity, social development and redistribution that inspired or analysed social economy practices. Sections 3 and 4 place the debate on the role of the social economy in a contemporary context-first, by looking at recent reconceptualisations of the social economy in the Francophone and Anglo-Saxon world (section 3) and, secondly, by validating the potential of these concepts for empirical analysis and practice-oriented research against both practitioners' views and the lessons drawn from the historical survey in section 2. Section 5 draws some methodological conclusions from this validation that are then elaborated in Moulaert and Nussbaumer (in this issue).

\section{The Emergence and Re-emergence of the 'Économie Sociale': Solidarity Practice and Social Economy Concepts}

'Social economy' in its various meanings and through its terminological space- and timebound proliferation, can only be analysed by combining a 'history of practice' with 'a history of thought perspective'. Section 2.1 provides a short, somewhat eclectic, historical 'Euro-centred' overview of social economy practice and organisation as they have inspired early Francophone conceptualisations of the social economy in Europe (section 2.2). This is the starting-point for laying the foundations of a theory of emergence and re-emergence of social economy practices, institutions and concepts for at least two time-perspectives: an epochal staging starting in the mid 19th century and a contemporary periodisation covering the past 30 years (section 2.3).

\subsection{A Short 'History of Practice' of the Social Economy}

Antiquity and medieval times. Defourny and Develtere (1997) and Demoustier (2001) retrace the ancient roots of the social economy within Egyptian corporations, the Greek funds for the ritual organisation of funerary ceremonies and the Roman colleges of craftsmen. The first guilds ${ }^{2}$ appeared in Germanic and Anglo-Saxon regions in the 9 th century and, in the 11 th century, there 
emerged the confraternities which responded to objective needs for assistance, reciprocal support and charity in the shaky early Middle Ages. The corporations (associations organised on the basis of a trade or a profession) and the first compagnonages (guilds) developed in the 14th century. ${ }^{3}$

The medieval epoch and beyond was characterised by a very rich associative life, not only in Europe, but also on other continents: the food corporations in medieval Byzantium, the post-medieval guilds in the Muslim countries, the professional castes in India, the confraternities of craftsmen in primitive Africa and in pre-Colombian America (Defourny and Develtere, 1997). These 'associations' were created in order to organise and protect communities.

The industrial revolution and the role of ideals in Europe. As Gueslin (1987) asserts, modern forms of social economy came into being as a result of theorising practical experiences and their institutionalisation in the 19th century, while the associative experiences of the 19th century took place in the context of a solidarity practice inherited from the late Middle Ages and the Renaissance. But until the French revolution, the associative organisations remained under the control of the Church or of the State. Clandestine associations-often savagely repressed by the authorities - would contribute to the dissemination of the 'new' idea of 'freedom of association'. It has been argued that the French revolution fostered political equality, meeting thereby the desire of the bourgeoisie. But the material inequality that remained was not dealt with until the 19th century (Hardy, 1979, p. 21).

The 19th century was, indeed, a formative century for the modern social economy, as it was characterised by an outburst of ideas, concepts, experiences, co-operative, associative or mutual aid practices, institutional and utopian initiatives in reaction to the social brutalities of the Industrial Revolution (poverty and exploitation), the emergence of the liberal philosophies and the actions taken by the state against the workers' movements or associations (Lévesque et al., 2001).
The 19th century-especially the second half - was also a period of intense experimentation with various forms of social action and initiatives in defence of the weakest segments of the population-i.e. the industrial workers whose numbers were growing significantly.

Before being institutionalised at the end of the 19th century or the beginning of the 20th century, the various forms of 'associationism' were inspired by a number of visions, ideologies, theories and philosophies, sometimes competing, that influenced the formation of the social economy. According to Defourny and Develtere (1997), the main ideas that played a fundamental role were: 18th and 19th century 'utopian socialism' (Owen, Fourier, Leroux, Saint-Simon, Proudhon) (Hardy, 1979; Mellor et al., 1988) that promoted the values of co-operation and of mutual support; Christian socialism that established the 'intermediary corps' to combat individual isolation and absorption of individuals by the state) ${ }^{4}$ (Defourny and Develtere, 1997, p. 3) and the liberal movement that favoured the mutual help associations by praising economic liberty and refusing state interference. These movements were not limited to one country, but spread all over Europe.

Defourny and Develtere (1997) show how all these important ideologies contributed significantly to the emergence of the social economy, but none of them can assert exclusive paternity. For instance, two contradictory tendencies characterised the French approach to the creation of associations: the republican ideal deriving from the French revolution that denied any organised mediation between the individual and the state, and the anti-individualist tendencies that stressed the importance of intermediary structures (Barthélemy, 2000, p. 15). In England, utopian socialism gave birth to many co-operative initiatives, where the community was considered the most appropriate body for achieving a harmonious society (Hardy, 1979, p. 20). However, each of these initiatives is connected to the specific needs of communities, protecting or promoting particular social relations. 


\subsection{Early Francophone Conceptualisation of the Social Economy}

First appearance of the term. The term économie sociale was used for the first time in 1830 by the French economist Charles Dunoyer (Nouveau traité d'économie sociale) in a meaning close to the contemporary use. Dunoyer was followed by the French Auguste Ott, who published his Traité d'économie sociale in $1851 .{ }^{5}$ But it was the French sociologist Frédéric Le Play who contributed significantly to the rise and acceptance of this concept in socioeconomic analysis. In 1856, he founded the Sociéte Internationale des Etudes Pratiques d'Economie Sociale and the Revue d'Economie Sociale and in 1867 he introduced the term économie sociale at the Universal Exhibition (Bidet, 1997, p. 31). In his programmatic text, he defines the social economy as

the study of the situation of the working class and of its relations with other classes (Topalov, 1999, p. 13).

Thanks to Charles Gide and later to Léon Walras (Etudes d'économie sociale, 1896), the term social economy received full academic and institutional recognition. Charles Gide (1912) defined the social economy as 'natural laws' that govern the spontaneous relations between people and things; it was the science of social justice, as distinct from political economy (i.e. the science of social utility).

According to Gide

The social economy ... could be defined in the strict sense: the study of all efforts made to improve the condition of the people (Gide, 1912, p. 10).

such as the workers' associations, the state (the social components of the state's policy), the capitalists (their charities) (Rapport sur le Palais de l'économie sociale de l'Exposition universelle de 1900).

For Walras, the social economy covers state action, which must play an essential role as the regulator of the market's excesses. Walras considered the conjugation of the (private) 'interest' (the market) and social justice (the task of the state) as a necessity: the Walrasian social economy appears as a contribution of the economic sphere to social justice (Bidet, 1997, p. 32). Walras distinguishes three levels of economic analysis: the pure political economy (the science of the production of wealth by the mobilisation of the individual interest, the science of the relationships between people and things), the applied economy (the study of economic resources as they relate to the laws of nature) and the social economy (the science of the distribution of wealth, of social justice) (Bidet, 1997; Demoustier, 2001; Walras, 1872-1874/1996, p. 115).

According to Desroche (1991), quoted by Bidet (1997, p. 32), this third component of the economy defined by Walras-i.e. the social economy-comprises both the philanthropic economy of private assistance and the economy of public services, with somewhere in the middle the 'solidarity economy' as defined by Gide.

The history of the social economy, as outlined above, goes back to the oldest forms of human association (Defourny and Develtere, 1997) but, according to Gueslin (1987), it was in the 19th century that the concept of a social economy was 'invented'. 6 This statement may sound boastful, but there are arguments in its favour: the emergence of the social economy as an explicit concept is the result of the institutionalisation and theoretical assessment of practical experiences, including experiences in earlier epochs such as the associations in the Middle Ages and those lived and described by early utopians and socialists. The end of the 19th century also marks the identification and the legal recognition of the three pillars of the social economy-i.e. the mutual support companies, co-operatives and associations-which, since the 19th century, have constituted the core of the social economy (Monzón Campos, 1997, p. 92).

\subsection{The Emergence and Re-emergence of the Social Economy}

Several authors contend that the emergence and re-emergence of the social 
economy-practice, concepts and policy/ institutions - is linked to periods of crisis: the social economy is a way to respond to the alienation and non-satisfaction of needs by the traditional private sector or the public sector in times of socioeconomic crisis.

Thus, Bouchard et al. (2000, p. 6) distinguish three generations of enterprises in the framework of what they call the 'old social economy', linked to the three big pre-war periods of crisis.

The first generation of social economy organisations emerged in the 1840s and $1850 \mathrm{~s}$, in the context of the transition from the old regulation (through craftsmen corporations) to competitive regulation. Thus, the mutual support organisations (mutuelles) appear in the middle of 19th century as a form of resistance of the workers grouped in corporations of craftsmen against deregulation of the associative economy, in order to secure protection against social risks (disease, accidents, death), professional risks (unemployment, strikes) or the alienation from basic needs (shelter, food) (Demoustier, 2001; Gueslin, 1987; Nussbaumer, 2002).

The second generation concerns the agricultural co-operatives and the saving cooperatives that rose in response to the needs of small producers affected by the crisis (1873-95) of the extensive regime of accumulation that required heavy investments in agriculture and natural resources (Boyer, 1986).

The third generation emerged from the economic collapse of 1929-32 and was to a large extent the result of the crisis in competitive regulation. The consumption cooperatives for food and housing supported workers and unemployed people to allow them to procure goods and services at affordable prices.

It should be observed that, during the postWorld-War-II period, some of the activities connected to the social economy became part of national institutions, as in France, where trade unions, as well as mutuelles or mutual aid associations, were recognised as 'partners' and participants in the welfare system. Significant sections of the social economy were integrated into the welfare system, while other activities remained connected to alternative philosophies and movements, as shown by the many co-operative activities that emerged from the 1970 alternative movements (Moulaert et al., 2005).

A periodisation in terms of specific crisis mechanisms can also be made for the recent period of capitalist history. In the 1970s, the initiatives in the field of social economy were, on the one hand, reactions to the crisis of the mass-production system and, on the other hand, responses to the overburdening welfare state. The return to 'small is beautiful' includes favouring the creation of SMEs for local economic development and the emergence of not-for-profit organisations with social objectives. The work co-operatives and collective services were designed to meet the need to work in a different way, favouring ecological and co-operative production; the goal was to establish a collective well-being and recreate social bonds between the people within their communities (Lipietz, 2003) in order to provide alternatives for services usually rendered by the state. ${ }^{7}$

The high unemployment in the 1980s and especially in the 1990s, and the loss of protection by the welfare system, explain the growing interest in the social economy: to seek solutions for the crisis of employment by the creation of entreprises d'insertion and of worker-owned co-operatives (Mellor et al., 1988). If in the 1970s the collective services belonging to the social economy offered alternatives to the state services, in the 1990s they also sought to satisfy the needs neglected by the state in the context of a crisis of public finance (Bouchard et al., 2000, p. 7). In France, the contemporary (as of the 1980s) re-emergence of the social economy as 'social and solidarity economy' is narrowly linked to the reaction against neo-liberal principles and individualist ideology

ce qui distingue l'économie solidaire, c'est tout de même que l'initiative vient de citoyen(ne)s résolu(e)s à faire quelque chose, parce qu'ils (elles) intègrent dans leur comportement individuel l'utilité pour tous, donc pour eux-mêmes, de retisser 
des liens sociaux, d'accumuler du capital social, d'améliorer leur environnement, de défendre leurs voisins (parce qu'avoir des voisins constitue souvent la première ressource) (Lipietz, 2001a, p. 51).

The 'solidarity economy' thus creates synergies between actors (local authorities, private enterprises, state, citizens) and generates workplaces by offering new services (for example, the associations for the development of proximity services, the French régies $d u$ quartier). ${ }^{8}$

\section{Contemporary Conceptual Elucidation: Defining 'Social Economy', 'Third Sector' and 'Solidarity Economy'}

How can we conceptualise the 'social economy' as it exists and is developing today? According to the approach used by Lévesque et al. (1999), there exists a 'third sector', different from the traditional public 'general interest serving' and the private market sectors, that combines: formal and informal elements at the level of organisation (market, state, volunteering, self-help and the domestic economy), market and nonmarket-oriented production and valorisation of goods and services, monetary and non-monetary resources at the level of funding.

Today, almost everywhere in western Europe, the US and eastern Europe, the 'third sector' (French troisième secteur or tiers secteur) co-exists with the private and public sectors. Terms such as social economy, third sector, solidarity economy "or alternative economy, non-lucrative sector, non-profit sector, not-for-profit sector, voluntary sector, idealist sector etc. are increasingly used as synonyms. In particular, the terms social economy, third sector and solidarity economy are often used interchangeably, thus overlooking the considerable differences in meaning in different countries, to which we want to turn our attention now. These differences frequently refer to the particular forms of 'co-existence' (such as relations of co-operation, dependency or control) of the private, public and third sectors in the various countries, their regions and cities. Setting some order to these terms and the concepts and contexts to which they refer is necessary.

\subsection{Terminological Synergies and Confusions}

Generally speaking, the term social economy designates the universe of practices and forms of mobilising economic resources towards the satisfaction of human needs that belong neither to for-profit enterprises, nor to the institutions of the state in the narrow sense. Today, the term is not only used in European debates but is also widespread in Latin European countries where the social economy has been addressed as an alternative to state socialism, making it also attractive to the church

Even if [in the 20th century] parts of the social economy have had views that not always have corresponded with the Church's, the social economy has been seen as an alternative to state socialism and hence been accepted by the Church (Westlund, 2003, p. 165).

Essentially, the social economy is made up of the voluntary, non-profit and co-operative sectors that are formally independent of the state. Their market activities are means of achieving social development goals that transcend the market per se. Thus defined, the social economy should be logically considered as a third sector (Browne, 1997, p. 1). In the US, the terms non-profit sector or voluntary sector are dominant: Salamon and Anheier underline that

there are those (de Tocqueville, 1835/ 1945; Hall, 1992) who believe that the 'non-profit sector' is a distinctively American concept, invented in response to America's distinctive tradition of individualism and hostility to statism, and its longstanding practice of organized action outside the confines of the State (Salamon and Anheier, 1994, p. 2).

Non-profit sector and voluntary sector combined are used as synonymous with third 
sector (Lorendahl, 1997, p. 76). According to Salamon and Anheier (1994, p. 3), "the UK shares with the United States a reasonably clear concept of a non-profit sector ('voluntary sector' in UK usage)". Still, in Anglo-Saxon terminology a distinction should be made between non-profit sector and not-for-profit organisations. Both types of organisation are guided by the principle of not making profits as the overriding motivation of their activity (Wolpert and Reiner, 1985). But in the first case making profits can be illegal and surpluses should be automatically allocated to the organisation's statutory activities (Ilczuk, 2001), whereas in the second case part of the profits can be divided among owners or shareholders - the latter referring to the continental European practice in co-operatives. The term third sector was put forward especially by Rifkin (1995), as comprising all the activities that are not public and not profit-oriented (Vuorinen et al., 1999). Rifkin makes a distinction between the North American and European use of the concept: while the Anglo-American charitable model refers mainly to non-profit organisations (associations and foundations, etc.), the continental European perception of the third sector also includes co-operative and mutual support organisations. Perri 6 and Vidal (1994; quoted in Vuorinen et al., 1999) stress that in the 1980s the expression third sector was used in a much narrower sense within the European context of 'the crisis of work and society'. In the sociological literature of the 1980s, the term was employed to include activities rejecting the (mainstream) capitalist (labour) market, whereas today it is studied as a way of expanding the social sphere of the market. According to Gaiger (2000), the use of the term 'third sector' supposes abandonment of the duality between social life (first sector) and economic life (second sector) and the market/state dichotomy

the so acclaimed Third-Sector's newness and innovator potential is justified only if it performs an innovator-constructor role of ways of development. This means to escape from the logic of the actors that have historically been occupied in development ... breaking the separation between economic life (Second Sector) and social life (First Sector) and suscitating protagonists that contain this possibility (Gaiger, 2000, p. 2).

Voluntary sector and non-statutory sector are concepts mainly used in the UK tradition. The term social economy is of relatively recent currency in the UK and its meaning is still evolving and susceptible to many often-contradictory interpretations (Pearce, 1999, p. 2; Amin et al., 2003). According to Defourny and Monzón Campos (1992), the term third sector is often used as the English translation of the French concept économie sociale (Lorendahl, 1997, p. 76) in order to distinguish that part of the national economy which is neither the private sector nor the public sector and to define all voluntary sector or voluntary organisation activity. The voluntary sector term embraces all those organisations, large or small, which are not part of the state or part of the private profit sector and will include very small community groups, social and sports clubs, all types of leisure groups as well as the major national charities. Recently, a useful distinction has been drawn within the third or voluntary sector between non-governmental organisations (NGOs) and community organisations: the former will be large and, despite their designation, often rely on state funding or contracts, while the latter will usually be smaller and quite independent, operating only at local community level (Pearce, 1999, p. 2). A remarkable conclusion from all these typologies is that the Anglo-Saxon literature devotes little attention to the role of market agents (co-operative firms, mutuelles, ...) which have managed to introduce modes of organisation based on solidarity and reciprocity, and serving niche markets formed by members or particular target user groups. In the (continental) European contexts, many of those are not charities or foundations but, using Gaiger's qualifications, a different articulation of 
social into economic life by often-powerful socioeconomic organisations and not only the petty underscaled or undercapitalised local initiatives of moaning communities (compare Amin et al., 2003).

As explained in section 2, the term économie sociale et solidaire is used quite frequently today, especially in Francophone literature (France and Québec). Jean-Louis Laville (1992) had defined the économie solidaire as a new generation of social economy with a plurality of forms of economic activities. The term économie sociale et solidaire is used to stress that the économie solidaire represents a re(emergence) of the 'old' social economy principles. According to Lipietz (2001a, p. 53), the social economy recognises in the solidary economy ${ }^{9}$ its 'prodigal child', and the économie solidaire sees in the social economy its slightly 'sclerotic parent'. This image is certainly exaggerated, but it has the advantage of expressing the necessity of a new approach to a different type of economy, that accounts more explicitly for the new challenges and recognises the general value of economic co-operation and reciprocity.

\subsection{The Social Economy: The Emergence of a Hybrid Typology}

Today, the social economy represents a wide family of initiatives and organisational forms-i.e. a hybridisation of market, nonmarket (redistribution) and non-monetary (reciprocity) economies showing that "the economy is not limited to the market, but includes principles of redistribution and reciprocity" (Laville, 1994, p. 10; Godbout, 2000). As a conclusion to this section, we try to synthesise the specific features of and the relations between the three concepts of third sector, social economy and solidarity economy, and to overcome blocks hampering the arrival at a comprehensive definition. We also refer to parallel concepts mentioned in the above text, which add omitted dimensions to the three core concepts. The main threads of the argument are presented in Table 1, which compares the main features of the three concepts according to their: institutional-political dimensions (from a historical perspective); property and control relations; type of 'core' agent; market orientation; model of co-operation; contemporary definitions and related concepts. These dimensions have a significant role in the analysis in Moulaert and Nussbaumer (in this issue).

Observe that in Table 1 a distinction is made between the encompassing concept of the 'social economy' as a whole and the 'social economy' as the more restricted economy of co-operatives and mutuelles. The Solidarity Economy is quite clear in its ambition to strengthen co-operation and solidarity among agents, mainly on a voluntary and reciprocity basis. In the UK and Ireland in particular, systems of non-monetised metrics of exchange (Amin et al., 1999) and in particular local exchange trade systems (LETS) are strongly developed pillars of the solidarity economy (O’Doherty et al., 1999; North, 1999). However, it leaves doubts about any potential links with the state or the market sector which might be brought about by aiming to create synergy, in the name of the same values, between the activities belonging to the third sector, the private sector and the public sector, or to the non-monetary sector (domestic, mutual aid etc.) (Lipietz, 2001a, p. 56).

The third sector concept which, as a possible consensus concept, expresses some general contemporary society tendencies, especially the formation of a third practice field, distinct from the private sector, with profit intention and of the state, is probably the most ambiguous (Fernandes, 1994, Gaiger, 2000, p. 24; CBS Network, 2003, p. 13). But although CBS does not do so, this third sector should be defined and analysed as connected to the other two. The first and second sector are defined first as a function of the type of actors (private enterprise, state departments) and second as referring to the mode of allocation of goods and services, whereas the variety of actors and modes of social interaction is the norm to define the third sector. The diversity of actors, institutional settings and activities or purposes of third-sector activities is not accounted for in this typology, whereas the variety of interactions and actors 
Table 1. Dimensions of social economy concepts: an overview

\begin{tabular}{|c|c|c|c|}
\hline \multirow[b]{2}{*}{ Concepts and dimensions } & \multicolumn{3}{|c|}{ Social economy } \\
\hline & Social economy & Third sector & Solidarity economy \\
\hline $\begin{array}{l}\text { 1. Institutional-political } \\
\text { dimensions and historical } \\
\text { perspectives }\end{array}$ & $\begin{array}{l}\text { 19th century: institutionalise better wages, better } \\
\text { work conditions, consumer satisfaction } \\
\text { 1930s: housing and food cooperatives to avoid blunt } \\
\text { poverty } \\
\text { 1970s: sustainable social entrepreneurship } \\
\text { post-1980s: worker-oriented co-operatives, LETS }\end{array}$ & $\begin{array}{l}\text { Immediate response to crisis of } \\
\text { work and society in the } 1980 \mathrm{~s}\end{array}$ & $\begin{array}{l}\text {.. reinforce institutional } \\
\text { capital }\end{array}$ \\
\hline 3. Type of 'core' agent & $\begin{array}{l}\text { Firms with social objectives or socially inspired work } \\
\text { organisations (co-operatives, mutuelles) }\end{array}$ & $\begin{array}{l}\text { Defined at level of sectoral } \\
\text { interaction (meso-economic) } \\
\text { or associative agents }\end{array}$ & Bottom-up initiatives \\
\hline 4. Market orientation & $\begin{array}{l}\text { Most core agents operate in the market but according } \\
\text { to solidarity principles }\end{array}$ & $\begin{array}{l}\text { Partly-quite eclectic definition } \\
\text { (see Lévesque et al., 1999) }\end{array}$ & $\begin{array}{l}\text { Neither market nor state? } \\
\text { Lipietz: synergies with market } \\
\text { and state sector }\end{array}$ \\
\hline Contemporary definition & $\begin{array}{l}\text { Historical-eclectically integrating, most dimensions } \\
\text { of social economy in previous epochs: social } \\
\text { objectives, reciprocity + solidarity, self- } \\
\text { management, state-regulated }\end{array}$ & $\begin{array}{l}\text { Social-economy initiatives by } \\
\text { agents in civil society } \\
\text { Associations }\end{array}$ & $\begin{array}{l}\text { Stressing rediscovery of } \\
\quad \text { lien social }\end{array}$ \\
\hline Related concepts & Non-lucrative sector & $\begin{array}{l}\text { Not-for-profit, independent } \\
\text { sector (UK) } \\
\text { Non-profit (US) }\end{array}$ & Voluntary sector \\
\hline
\end{tabular}


(and their agendas) do not play a role in the definition of sectors 1 and 2 . This leads to unbalanced and incomplete definitions of all sectors, easily generating analytically useless conclusions about 'bad market firms' and 'good community LETS'. In fact, to talk in a balanced way about the different sectors in the economy, and within the social economy, it is important to look at all five dimensions of each concept, and understand why they differ in relevance. For example, in LETS as a form of solidarity economy, a large component of voluntary work and reciprocity in delivery relations is of higher relevance than in the economie sociale co-operatives and mutuelles where the ethics and practice of shared control and ownership relations are key to the reproduction of its institutions.

Finally, to make progress with a comprehensive definition of the social economy, we should step beyond the question of whether social economy activities (can) make profits or not. The literature on the social economy is characterised by an ambiguity about the orientation of financial benefits: an ideell or non-lucrative association can make profits (considering the profits as a surplus return to investment after having paid all partners), but these cannot be distributed to its members. But, on the other hand, cooperatives distribute their profits to their members, in proportion to their purchases or their supplies of goods and services. Lorendahl (1997, p. 76) observes the tendency among American scholars to exclude cooperatives and mutual aid organisations as associations (associative sector or third sector in the limited sense) because of their commercial character. In contrast, European definitions of social economy and of third sector, usually include the co-operatives, the mutual aid associations (mutuelles) and the organisations of commercial character. ${ }^{10}$

\section{The Role of Practice and History in Analysing Today's Social Economy}

In the second section of this paper, we stressed the existence of a clear correspondence between the manifestations of the big socioeconomic crises and the emergence of the various forms of social economy. Certainly, the economic crises of the 19th and 20th centuries had a considerable impact on the emergence of various initiatives and organisations of the social economy seeking to provide appropriate answers to the needs which the troubled mechanisms of the market or the less flexible mechanisms of the state fail to satisfy. In the third section, we provided an overview of contemporary reconceptualisations of the social economy, in the light of various national approaches_-stressing the Francophone and Anglo-Saxon-while keeping a record of the historical roots of the various concepts and definitions. Weak points of the reconceptualisation turned out to be: the non-reflexive diversity of focal agents and activity agendas, the superficial analysis of organisational relations-including the governance of the social economy and especially the role of property and control relations. Neglect of the articulation between different spatial and institutional scales of the social economy and its governance should be added to this list. Untreated up to now, this will be a concern of practitioners in the social economy (section 4.1).

In this fourth section of the paper, we seek to improve the connection between contemporary concepts of social economy, social economy practice experiences and lessons from the 'historical' definitions surveyed in section 2. These connections should lead to a more context-grounded and institutionally embedded conceptualisation of the social economy.

\subsection{Practice-oriented Challenges: Orienting the Definition and Delimitation of Social Economy towards Human Needs}

Strangely enough, many of the academic definitions of social economy hardly speak of the needs they address. In practice, however, these (often-unsatisfied) needs are where the logic of the social economy is rooted. Human needs are multiple and continuously developing. Despite the knowledge that the finality of all productive activity is the satisfaction of these needs, the market 
and public sector increasingly fail to satisfy them, especially when the potential users are financially deprived citizens or groups operating in the margins of mainstream society.

At the same time, important groups of unemployed are no longer or have never been involved in productive activity; naturally speaking, many of these unemployed people could be at work in activities satisfying unsatisfied human needs. According to Weitzman (1987; quoted by Monzón Campos, 1997), involuntary unemployment is the most expensive failure of capitalism, but the macroeconomic explanations based on the rigidity of real wages and on the non-flexibility of the labour market are not sufficient to account for the size and variety of the phenomenon. Monzón Campos (1997) shows that the organisations of the social economy (especially workers' co-operatives) are efficient instruments for economic stabilisation-they produce more stable workplaces than the traditional enterprises, for the allocation of resources and for the distribution of incomeideal forms for the allocation of public services in the social field, for the professional reemployment of workers and for the generation of a culture of responsibility and participation.

Monzón Campos' analysis is reflected in the operational definitions provided by 'local' and 'global' organisations working with or co-ordinating micro social economy initiatives. The satisfaction of various basic needs is the most straightforward socioeconomic objective put forward in contemporary practice-oriented definitions of social economy. ${ }^{11}$ It is in general mentioned in combination with the criteria of the organisation of allocation systems (market, state, redistribution, LETS) and production organisation, both from a technical and a social point of view. Let us briefly look at three 'operational' definitions of the social economy: one in the UK, one at the EU level, one in France.

\section{CAN consultants. According to CAN consultants,}

The social economy is the sector of activity that functions for social purposes. It seeks to achieve all or some of the following criteria: sustainable and self financing activity, of benefit to those who are involved in it, to address the needs of those who are currently disadvantaged, to encourage the ethic of self-help, to replace dependency with self reliance, to enhance the social fabric of a community (CAN consultants, 2002). ${ }^{12}$

INTEGRA (part of an EC EMPLOYMENT measure). For the EC's INTEGRA,

The social economy may be seen as a new, or newly defined, arena of economic activity which:

- straddles the market, the state and nonmarket sectors (the latter includes activities traditionally falling within systems of care and reciprocity in families and neighbourhoods, child-care and the care of the elderly)

- serves social as well economic ends

-operates on the principles of solidarity and sustainability rather than profit (INTEGRA). ${ }^{13}$

Economie sociale in the Poitou-Charente region. The definition that is provided here is quite inductive. First, the types of organisation that are involved are listed: co-operative enterprises, mutual aid societies and not-forprofit organisations. ${ }^{14}$ These activities are built on common values: solidarity is more important than financial resources; freedom of membership; democratic management and decisional transparency (each member has one voice, one vote). Further reading of this website shows the importance of the connection between the social economy as a vehicle of local development and social emancipation.

Discussion. What do we learn from these 'practice' definitions? First, there is a strong focus on production agents, rather than, as in many of the theoretical definitions, on opaque systems including various types of non-defined agents that work as invisible hands in the three sectors of the economy.

Secondly, these agents' activities are defined in the first place with reference to what they produce-usually for the 
satisfaction of needs neglected by 'either market or state' - and in the second place by describing their modes of organisation and institutionalisation. There is more interest in analysing the modes of governance of social economy organisations in these practiceoriented definitions, than in the conceptual analyses we addressed in the previous sections. Still in these practice-based definitions, there is little focus on the modes of allocation of the production output. Needs are not necessarily defined on the basis of material existential principles, social organisational principles also play a part: solidarity and reciprocity in human production and allocation relations are explicitly recognised as human needs by many of the social economy organisations and needs satisfaction is pursued by social innovation in the governance of these organisations.

Thirdly, in most cases the link between social economy and local development is explicitly recognised: it is assumed that successful experiences are embedded in specific territorial contexts. These assumptions are often based on satisfactory experiences, sounding-out a more positive discourse on the 'local social economy' than that developed by Amin et al. (2003).

Fourthly, as in the theoretical debates, there is an explicit reference to the ethical values of solidarity and reciprocity. Again, as in the theoretical analysis, there is a recognition that the social economy is a wide-spectrum reality ranging from market firms with a partially social agenda to purely solidarity firms or LETS initiatives where the capitalist market mechanism is completely neutralised.

Fifthly, there is an explicit concern about the 'higher' levels of governance, the need to provide stabilising levers and institutions that will guarantee the positive impact of the social economy on the economy and society as a whole and, at the same time, provide the instruments needed to make the social economy work. These higher levels of governance are not necessarily the national state or protected niche markets-although these can be very effective-but can be networks established between social economy initiatives themselves (Perna, 1998; Moulaert et al., 2002, ch. 6).

\subsection{Historical Lessons}

There is a striking correspondence between the 'lessons from practice' and the lessons from history (of practice and of thought) we looked at in section 2. The modes of organisation of the social economy and their institutionalisation in a particular period and context, the strong concern about higher levels of governance and the explicit link to ethical values found in the historical analysis are also shared by contemporary definitions. But there are also meaningful differences, of which we will identify only two here.

The first, which also has an impact on identifying the second, is the dynamic intertemporal perspective of historical analysis and the socio-political cycles it identifies. Very relevant here is the historical meaning of scale dynamics: the history of the 19th-century social economy shows the evolution of small local initiatives (co-operatives, support organisations) to national-and from the ideological-political perspective also international-initiatives such as the creation of nation-wide co-operatives and their associations, the design and approval of legal instruments to guarantee their operations. This 'up-scaling' of the social economy received a major new impetus under Fordism, when the national social security and welfare systems integrated part of, or worked out, a division of labour with social economy institutions (especially mutual support organisations). When, in the 1970s, Fordism entered a major crisis, this also provoked reactions among the 'new' social economy initiatives against large institutions, paternalist welfare agents, suffocating public bureaucracy, etc. This, together with the strong focus on local development, explains why today's social economy initiatives, despite their concern about 'up-scaling their governance', are not well organised at higher spatial scales, cannot benefit from proper legal instruments guaranteeing their sustainability and show a grand amateurism regarding their financial structure. 
This leads us to the second major difference from the lessons from history. History shows the importance of the material infrastructure of social economy initiatives. Today, this dimension remains neglected: the solidarity economy must rely either on short-term funding from public agencies (as in the insertion par l'économique) and grants through charities-which are not well defined in the continental European system, or through pseudo-market schemes as in the UK's 'New Deal' third-sector initiatives-preparing social economy initiatives to reintegrate with the market. The co-operative economy is looking for a new institutional impetus and framework, but nation-states are not providing it at present. History learns that the social economy needs its own funding schemes, temporalities and supralocal governance dynamics. A concrete example is the funding basis of the 19th-century co-operatives and their rights to make profits, if reinvested or distributed according to the norms of the social economy. But also the long-standing tradition of non-profit organisations in the US offers a much sounder financial basis for social economy initiatives than the idealist contemporary constructions in continental Europe today.

In its criticism of the European co-operative model, the Anglo-American view of funding the social economy does not stress sufficiently that many co-operatives were created in response to a mutual or general interest of historical relevance (example: producing and distributing decent affordable food to the working class which was initially forced to buy overpriced foodstuffs from the 19thcentury factory shop). Egalitarian property rights and mutual interest (satisfaction of basic needs) were usually two criteria for the creation of co-operatives by the working class; and these principles are also recognised in social economy practice today. Still, despite these differences in reading history lessons, features of the many co-operative and communitarian initiatives in the US (see, for example, Bruyn and Meehan, 1987) could be purposefully integrated into future operational models and legal frameworks of social economy in Europe, thus improving their effectiveness.

Other lessons can be drawn from confronting contemporary concepts and practice within an historical perspective. We think for example of the absence of social philosophies in justifying contemporary social economic practice-while they were very present in the social economy initiatives in other periods of history, the translation of the 'globalisation' of the social economy in the 19th century to problems of multilevel governance today (for example, maybe the need for an 'international' of social economy organisations), learning from historical experiences in overcoming the tension between specific community needs and the political realism of wide-scale change movements. These issues are taken up in the paper by Swyngedouw (in this issue).

\section{Conclusions}

Because of the challenges stemming from day-to-day practice and the specific outcomes of historical dynamics, it is very difficultand probably not scientifically useful-to reconcile the wide world of initiatives and activities connected to social economy in a 'one for all' definition. Social economy is so much embedded in historical, institutional and local contexts that it seems to escape generalisation. Still, some guiding principles emerge from the variety of experiences and their analysis.

The first is the refutation of the traditional polarising views on production, distribution and exchange. The real-life spectrum of initiatives and institutions lying between pure market functioning and state administration is wide. It seems that social economy develops as a permanent stream of inventions of various social mechanisms, mixing market exchange, state intervention, collective civilsector organisation based on social movements driven by solidarity and reciprocity. The concomitance of the development of social economy and socioeconomic crises can be interpreted in these terms.

Dissatisfaction and frustration due to both state intervention and market failures, 
widespread state and market paternalism or micro-community powerlessness leave a place for the use of other (often pre-existing) social bonds in meeting natural, psychological and cultural needs. This is where social innovation plays an important role in the social economy: social innovation means innovation in social relations as well as new modes of satisfying needs. Still, social innovation does not mean that new social bonds emerge ex nihilo, but instead arise in ways more like a reinterpretation or reproduction of already lived social relations but within new contexts (see González and Healey, in this issue). These new contexts, however, are embedded in a multiscalar society entangled in webs of power relations (see Swyngedouw, 2005 in this special issue).

The analytical work on defining the social economy and its governance as required by today's unmet economic, social and political needs, has not progressed very significantly yet. The social economy is presented as a family of hybrids between market, state and civil society; but this traditional social science 'classificatory' approach does not lead to an operational definition of the social economy. A proper analysis of the features of each of these 'allocation systems' must be left to empirical analysis that shows the immense diversity of social economy patterns. A definition of the term must account for the many forms of social relations that exist and their embeddedness in specific social, cultural, historical and institutional backgrounds.

At least two questions remain to be addressed while considering the history of the concept of the social economy. Does the diversity within social economy concepts and practices leaves a space for a normative approach that could help to improve the social efficiency of the various initiatives? Are there any guidelines that could enable the evaluation of the social economy? This issue is important for understanding what is meant by good governance for the social economy (see Moulaert and Nussbaumer, in this issue). It also leads us to a second question that rises from the analysis of past experiences. Is a social economy 'sustainable' and under which criteria? The utopian communities in 19th-century England definitely failed and collapsed (see Hardy, 1979). The third sector in France and also in Quebec is often threatened by financial bankruptcy (Nussbaumer, 2002). And the state's fluctuating commitment to social economy, essential to its durability, is a source of uncertainty for the future (see Lévesque et al., 2001; Lipietz, 2001). This second question also relates to the problem of different temporalities in the social economy: the time needed to implement an 'alternative' investment project, the time it takes to transform state governance of the social economy into a system supportive to durable strategies, etc., hardly ever match.

The last paper in this Special Topic (by Moulaert and Nussbaumer) offers a clearer methodological positioning for defining the social economy. A distinction will be made between an essentialist and a holistic definition of the social economy. An essentialist definition uses abstract categories only and claims in its abstraction a conceptual generality for a variety of specific phenomena and situations (historical epochs, territorial dynamics, institutional contexts). A holistic definition in contrast does not pursue generality, but inclusiveness. A holist theory focuses on the dialectics between general mechanisms, on the one hand, and specific situations on the other hand. A holist definition, therefore, looks more like a dialectal argument between generality and specificity, taking into account history, institutions and territorial context, practice and reflection; it takes distance from an omni-valuable formula as provided in an essentialist definition.

\section{Notes}

1. In this paper, we use the term 'social economy' with two meanings; first, as an general overarching concept, 'a family name' representing a wide variety of other terms which themselves cover diverse features; secondly, as a comprehensive, more tightly defined concept which we hope to elaborate in this paper, and in 
Moulaert and Nussbaumer (in this issue). The terminological wealth in social economy literature is legion, but does not arrive at a conflation of terms, only at highlighting particular dimensions of the social economy which receive specific names in particular social and historical circumstances.

2. The aims of the guilds (associations of craftsmen) are to guarantee mutual aid and to protect their members from improper competition.

3. Associations of workers, securing lodging, food, education and social protection for the 'companions'. The Société des fourreurs de vair appeared in Paris in 1319, as a society of mutual support, providing its members with support when they fell sick or unable to work.

4. D'une manière générale, les chrétiens sociaux du XIXe siècle appellent de leurs voeux des 'corps intermédiaires' pour lutter contre l'isolement de l'individu, tare du libéralisme et contre l'absorption de l'individu dans l'Etat, piège du jacobinisme (Defourny and Develtere, 1997, p. 3).

5. Auguste Ott (1814-1903), French lawyer, essayist and journalist was interested in philosophy and political economy.

6. Meaning that 'inventing' things often happens after they have been around for a while.

7. Avec la crise des années 70 , de petites structures empruntent les mêmes formes juridiques, mais en retrouvent la mystique originelle. Elles mettent en avant l'idée de "travailler autrement", l'idée "d'autonomie" et choisissent leur activité pour servir la communauté bien au-delà des besoins de leurs clients directs. On veut recréer du lien social, entre les gens, redonner du sens à ce qu'on fait, commercer avec son voisin (ou des fournisseurs d'un autre continent) pas seulement pour l'intérêt du produit, mais pour se sortir tous ensemble de la crise. Dans cette économie sociale ET AUSSI solidaire, l'écologie (le rapport entre tous les humains par le biais de leur environnement) devient une préoccupation cardinale. Il faut produire, mais produire du bien-être collectif et pourquoi pas du bonheur (Lipietz, 2003).

8. A type of association that appeared in 1980 in Roubaix, Meaux, Marseilles and Besançon (cities in France), which join together local communities, organisations of social housing and inhabitants to manage their territory. The technical mission (maintenance of housing, of green spaces, the animation of the neighbourhood, etc.) is combined with a broader objective (recreation of social links, creation of workplaces, participation to the political life, etc.).

9. The term 'solidary' is not proper English, but is also in English increasingly used as an adjective in contemporary debates on 'solidarity' bonds in co-operative organisations.

10. L'économie sociale ... regroupe une large variété d'organisations à but lucratif comme les sociétés d'assurances mutuelles, les banques d'épargne, les coopératives et les organisations de commercialisation agricoles qui pourraient être considérées comme incluses dans la sphère commerciale (Salamon and Anheier, 1992, p. 129; quoted in Lorendahl, 1997, p. 76).

11. Basic needs can be biological (food, rest), bio-psychological (clothing, shelter), psychological (knowledge, relational) or sociocultural (intellectual, autonomy) (see Ekins and Max-Neef, 1992).

12. CAN is a workers co-operative of specialist trainers and consultants. Established in 1989 , CAN draws on a wide range of experience in developing the social economy sector and is now recognised as a leader in the field (http://www.co-op-assist.co.uk/ socecon.htm\#cda).

13. In May 1996, the European Commission introduced a new strand to the EMPLOYMENT Initiative called INTEGRA. This replaced the Horizon Disadvantaged Strand. This information has been obtained from a publication by the Irish part of Integra entitled The social economy: potential and pitfalls (Integra Review, 2, Winter 1996; available at http://www.iol.ie/ EMPLOYMENT/integra/sepp.html).

14. See http://www.cres-pch.org/cestquoi/ default.htm. Persons do not become members as shareholders-associations are governed according to democratic principles and not as a function of the financial capital that members provide. 'One person, one vote' is one of the formal rules of the social economy. Georges Fauquet (1935/ 1965 ) suggests the notion of 'associations de personnes' to illustrate this principle.

\section{References}

Amin, A., Cameron, A. and Hudson, R. (1999) Welfare as work? The potential of the UK social economy, Environment and Planning A, 31, pp. 2033-2051.

Amin, A., Cameron, A. and Hudson, R. (2003) The alterity of the social economy, in: R. LEE, A. LEYshon and C. WILliams (Eds) Alternative Economic Spaces, pp. 27-54. London: Sage. 
BARThÉlemy, M. (2000) Associations: un nouvel âge de la participation? Paris: Presses de Sciences Po.

Bidet, E. (1997) L'économie sociale. Paris: Le Monde-Editions.

Bouchard, M., Bourque, G. and Lévesque, B. (2000) L'évaluation de l'économie sociale dans la perspective des nouvelles formes de régulation socio-économique de l'intérêt général. Working Paper No. 0013, Cahiers du CRISES.

BOYER, R. (1986) La théorie de la régulation: une analyse critique. Paris: La Découverte.

BRownE, P. L. (1997) The two faces of the social economy. Paper presented at the Eighth Conference of Canadian Welfare Policy, University of Regina, Saskatchewan, June.

Bruyn, S. T. and MeEhan, J. (1987) Beyond the Market and the State: New Directions in Community Development. Philadelphia, PA: Temple University Press.

CBS (COMmunity Business Scotland) NETWORK (2003) Social enterprise development and the social economy in Scotland (http:// www.cbs-network.org.uk).

Defourny, J. and Develtere, P. (1997) Jalons pour une clarification des débats sur l'économie sociale. ADA (Appui au Développement Autonome) Dialogue No. 2, Luxembourg (http:// www.globenet.org/horizon-local/ada/9721.html).

Defourny, J. and Monzón CAmpos, J. L. (1992) Économie Sociale-Third Sector. Brussels: De Boeck.

Demoustier, D. (2001) L'économie sociale et solidaire: s'associer pour entreprendre autrement. Paris: Syros.

Desroche, H. (1991), Histoire d'économies sociales. D'un Tiers État aux Tiers secteurs. (1791-1991). Paris: Syros-Alternatives.

Dunoyer, CH. (1830) Nouveau traité d'économie sociale, ou simple exposition des causes sous l'influence desquelles les hommes parviennent à user de leurs forces avec le plus de LIBERTÉ, c'est-à-dire avec le plus FACILITÉ et de PUISSANCE. Paris: Sautelet.

Ekins, P. and MaX-NeEF, M. (1992) Real-life Economics: Understanding Wealth Creation. London: Routledge.

FAUQUET, G. (1935/1965) Le secteur co-operatif. Paris: Institut des études co-operatives.

Fernandes, R. C. (1994) Privado, porém público: o terceiro setor na América Latina. Rio de Janeiro: Relume-Dumará.

GAIGER, L.-I. (2000) Solidary popular economy in third-sector Horison. Paper presented at the ISTR Fourth International Conference, Dublin, July.

Gide, C. (1912) Les Institutions de Progrès Social. Paris: Librairie de la Société du Recueil Sirey.
Godbout, J. (2000) Le don, la dette et l'identité: L'homo donator vs homo xeconomicus. Paris: La Découverte.

Gueslin, A. (1987) L'invention de l'économie sociale. Paris: Economica.

HALL, P. (1992) Inventing the Nonprofit Sector. Baltimore, MD: The Johns Hopkins University Press.

HARDY, D. (1979) Alternative Communities in Nineteenth Century England. London: Longman.

Ilczuk, D. (2001) Private action for the public good: regulations, incentives and examples of practice (http://www.coe.int/).

LAVILLE, J.-L. (1992) Les services de proximité en Europe. Paris: Vuibert.

LAVILLE, J.-L. (Ed.) (1994) L'économie solidaire, une perspective internationale. Paris: Desclée de Brouwer.

Laville, J.-L. and Delfau, G. (2000) Aux sources de l'économie solidaire. Domont: Ed. Thierry Quinqueton.

Lévesque, B., Bourque, G. L. and Forgues, E. (2001) La nouvelle sociologie économique. Paris: Desclée de Brouwer.

Lévesque, B., Malo, M.-C. and Girard, J.-P. (1999) L'ancienne et la nouvelle économie sociale, in: J. Defourny, P. Develtere and B. FontenEAu (Eds) L'économie sociale au Nord et au Sud, pp. 195-216. Paris: De Boeck \& Larcier.

Leyshon, A., LeE, R. and Williams, C. C. (Eds) (2003) Alternative Economic Spaces. London: Sage.

LiPIETz, A. (2001a) Pour le tiers secteur. L'économie sociale et solidaire: pourquoi, comment. Paris: La Découverte.

LiPIETZ, A. (2001b) Du halo sociétal au tiers secteur: pour une loi-cadre sur les sociétés à vocation sociale, in: C. Fourel (Ed.) La nouvelle économie sociale: efficacité, solidarité, démocratie, pp. 27-42. Paris: La Découverte \& Syros.

LiPIETZ, A. (2003) Travailler autrement, pour autre chose, Vert Mensuel, 3(December) (http:// lipietz.net/article.php3?id_article=1162).

LORENDAHL, B. (1997) L'intégration de l'économie publique et de l'économie sociale et coopérative: vers un nouveau modèle suédois?, in: L. Monnier and B. Thiry (Eds) Mutations structurelles et intérêt général, pp. 73-88. Bruxelles: De Boeck.

Mellor, M., Hananh, J. and Stirling, J. (1988) Worker Cooperatives in Theory and Practice. Milton Keynes: Open University Press.

Monzón CAMPOS, J. L. (1997) Les contributions de l'économie sociale à l'intérêt général, in: L. Monnier and B. Thiry (Eds) Mutations structurelles et intérêt général, pp. 89-100. Bruxelles: De Boeck. 
Moreau, J. (1994) L'économie sociale face à l'ultralibéralisme. Paris: Syros

Moulaert, F. (2002) Globalization and Integrated Area Development in European Cities. London: Oxford University Press.

Moulaert, F., Martinelli, F. and SwyngeDOUw, E. (2005) Social innovation, governance and community building. EC FP6, Final Report. Lille/Newcastle, IFRESI and GURU.

NoRTH, P. (1999) Explorations in heterotopia: Local Exchange Trading Schemes (LETS) and the micropolitics of money and livelihood, Environment and Society D: Society and Space, 17, pp. 69-86.

NussB AUMER, J. (2002) Le rôle de la culture et des institutions dans les débats sur le développement local: la contribution de l'Ecole Historique Allemande. $\mathrm{PhD}$ Thesis, Lille: University of Lille I, Faculty of Social Science.

O'DOHERTY, R. K., DURRSCHMIDT, J. and Purdue, D. A. (1999) Local exchange and trading schemes: a useful strand of community economic development policy?, Environment and Planning A, 31, pp. 1639-1653.

Отт, А. (1851) Traité d'économie sociale. Paris: Renou-éditeur.

PeArCe, J. (1999) Epose Regional ReportCommunity Business Scotland Network. CBS Network, Edinburgh: Princes House (http:// www.cbs-network.org.uk/EPOSErep.html).

Perna, T. (1998) Fair Trade. La sfida etica al mercato mondiale. Torino: Bollati Boringhieri, 1998.

Perri 6 and Vidal, I. (1994) (Eds) Delivering Welfare: Repositioning non-profit and cooperative action in Western European welfare states. Barcelona: Centre d'Iniciatives de l'Economia Social (CIES).

RAHnema, MA. (2001) La production de la pauvreté moderne, L'Écologiste, 2(4), pp. 29-32.

Rifkin, J. (1995) The End of Work: The Decline of the Global Labor Force and the Dawn of the Post-market Era. New York: G.P. Putnam's Sons.
Salamon, L. M. and Anheier, H. K. (1992) In the search of the nonprofit sector. I: the question of definitions, Voluntas, 3(2), pp. 125-151.

Salamon, L. M. and AnheIer, H. K. (1994) Caring sector or caring society? Discovering the nonprofit sector cross-nationally. Working Papers on the Johns Hopkins Comparative Nonprofite Sector Project, Institute for Policy Studies, The Johns Hopkins University.

Salamon, L. M. and Anheier H. K. (1995) The Emerging Sector: The Nonprofit Sector in Comparative Perspective. An Overview. Baltimore, MD: Johns Hopkins University.

Tocqueville, A. DE $(1835 / 1945)$ Democracy in America. New York: Alfred A. Knopf, Inc.

Topalov, C. (1999) Les 'réformateurs' et leurs réseaux: enjeux d'un objet de recherche, in: C. Topalov (Ed.) Laboratoires du nouveau siècle: la nébuleuse réformatrice et ses réseaux en France, 1880-1914, pp. 11-58. Paris: Editions de l'École des Hautes Études en Sciences Sociales.

VUORINEN, P. ET AL. (1999), Elargir le Marché du Travail pour une Cohesion Sociale. une recherche d'initiatives pour la création d'emplois. Final report for the Council of Europe. Office of the European Committee for Social Cohesion, 2nd meeting, Strasbourg, June (http://www.coe.int).

WAlras, L. (1872-74/1996) Cours. Paris: Economica.

WALRAS, L. (1896) Etudes d'économie sociale (Théorie de la répartition de la richesse sociale). Lausanne: F. Rouge.

Weitzman, M. L. (1987) La economía de participación. México: Fondo de Cultura Económica.

Westlund, H. (2003) Social economy and employment: the case of Sweden, Review of Social Economy, 61(2), pp. 163-182.

Wolpert, J. and ReINER, T. (1985) The not-forprofit sector in stable and growing metropolitan regions, Urban Affairs Quarterly, 20(4), pp. 487-510. 
Copyright of Urban Studies is the property of The Editors of Urban Studies. The copyright in an individual article may be maintained by the author in certain cases. Content may not be copied or emailed to multiple sites or posted to a listserv without the copyright holder's express written permission. However, users may print, download, or email articles for individual use. 